\title{
Organic Dust in Feed Industry
}

Original Research

\author{
Pawel Sobczak ${ }^{1 *}$, Kazimierz Zawiślak ${ }^{1}$, Wioletta Żukiewicz-Sobczak ${ }^{2}$, \\ Paula Wróblewska ${ }^{2}$, Piotr Adamczuk ${ }^{2}$, Jacek Mazur'1, Marta Kozak ${ }^{1}$
}

${ }^{1}$ Department of Food Engineering and Machines, University of Life Sciences, Poland

${ }^{2}$ Department of Allergology and Environmental Hazards, Institute of Rural Health, Poland

\author{
Received: February 11, 2015 \\ Accepted: April 15, 2015
}

\begin{abstract}
An important issue for the feed industry is the evaluation of occupational exposure to dust that occurs in processing plant workstations. The most dust-generating processes include milling, crushing, sifting, transporting, and mixing of powdery/loose materials. Organic dusts vary in terms of both the dimensions of the particles therein and microbiological contamination. This article presents the results of an analysis aimed at determining the working conditions at various workstations in a feed plant. Three air measuring points were selected: the comminution stage, the granulation process, and the packing stage. Assessment of the concentration of dust particles suspended in the air was made using the dust meter, and then microbiological analysis was carried out in order to identify the number and species of fungi in the respective fractions of the organic dust. Research on present concentrations of airborne organic dust has led to the conclusion that the highest shortterm exposure concentration of dust was recorded at the granulation stage. The dominant airborne microflora in the feed mill was composed of mould fungi of genus Aspergillus: candidus, flavus, and fumigatus.
\end{abstract}

Keywords: dust, contamination, moulds

\section{Introduction}

The problem of dust contamination in the feed and grain storage industry remains relevant. It requires multiple actions at various stages of production in order to protect workers from its adverse effects. The dust that is inhaled during work is not noticed in spite of conjunctival irritation or obstruction of the nasal mucosa [1-3]. Micro-organisms (gram-negative bacteria, thermophilic actinomycetes, mould fungi) and endotoxins are the main biological harmful agents of agricultural dusts. Assessment of occupational exposure to dust in feed industry is a complex process aimed to determine the health importance of detected and quantitatively marked adverse factors present in the work environment. This is in order to protect workers who are within range of these agents against diseases [4-6]. Harmful effects of dust on the human body can cause many diseases,

*e-mail: pawel.sobczak@up.lublin.pl including pneumoconiosis, cancer, asthma, toxic organic dust syndrome (grain fever), and miller's lung [7-11].

Dusts are formed at different stages of production. The most dust-generating processes include milling, crushing, sifting, transporting, and mixing of powdery/loose materials. Organic dusts of plant origin constitute a huge family of dusts whose primary matter is composed of particles of different plants. They are usually mixtures in which, besides the plant particles, there are also inorganic particles and richly represented microflora and macroflora, together with substances produced by them [12]. In general, it can be stated that in almost all organic dusts of plant origin there are microorganisms and endotoxins. The presence of free silica is confirmed for the majority of these dusts. The highest content of $\mathrm{SiO}_{2}$ in the dust inhaled (reaching up to $60 \%$ depending on the type of soil), is present in the phase of the plant material production and obtention. Then it falls to below $10 \%$ in later stages of processing. The highest concentrations of dust is detected in the following worksta- 
tions: feed mixing, reception of grain in warehouses and elevators, and packaging. Organic dusts of plant origin are varied in terms of the size of the particles they contain. The fraction share expressed in the number of particles $<5$ $\mu \mathrm{m}$ is within the range of $40 \div 98 \%$, and expressed in the weight of these particles reaches $60 \%$. Just as for the composition and particle sizes, the concentration of the inhaled dust in particular workstations also varies significantly ranging from fractions of milligrams to more than 100 milligrams in $1 \mathrm{~m}^{3}$ of air $[13,14]$.

Our research of dust concentration and analysis of collected air samples for the presence of mould fungi in the workplace aimed to evaluate the working conditions at various workstations in a feed plant.

\section{Methodology}

Three air measuring points were selected. The first point was set up at the comminution stage of the feed material. The second point was selected at the granulation process, and the third at the packing stage. The measurement points are marked on the schematic diagram of a feed plant (Fig. 1).

In each of the selected points test samples of air were collected with five repetitions and analysed in terms of dustiness.
Assessment of the concentration of dust particles suspended in the air was made using a DustTrak II dust meter, which operates on the principle of laser photometer measuring in real-time the concentration of aerosol in the tested air. The study was performed using four filters to analyse the particle size of the dust, i.e. $10,4,2.5$, and $1 \mu \mathrm{m}$. The finest filter was used to measure the total dust concentration in the plant. Analyses were carried out using a 6-stage viable (microbial) cascade impactor Andersen TE-10-800 (TISCH) directly to two culture media: MA (malt agar) and PDA (potato dextrose agar) in order to identify the number and species of fungi in the respective fractions of the organic dust.

Construction of the Andersen cascade impactor allows us to determine the respirable microbial aerosol fraction that is the constituent that has the potential capacity of penetration into alveoli of the human body. Each stage has 400 orifices with a diameter of $1.18 \mathrm{~mm}$ at the first stage to $0.25 \mathrm{~mm}$ at the sixth. Considering the size of the orifices at the particular stages, microorganisms reaching the second stage enter the throat, the third enter the trachea and main bronchi, the fourth enter the intermedial bronchi, the fifth enter the bronchioles, and the ones reaching the sixth stage of the impactor enter the human alveoli. The use of an Andersen cascade impactor allows us to analyse collected air samples for the presence of mould fungi in the workplace and determine their potential danger to humans.

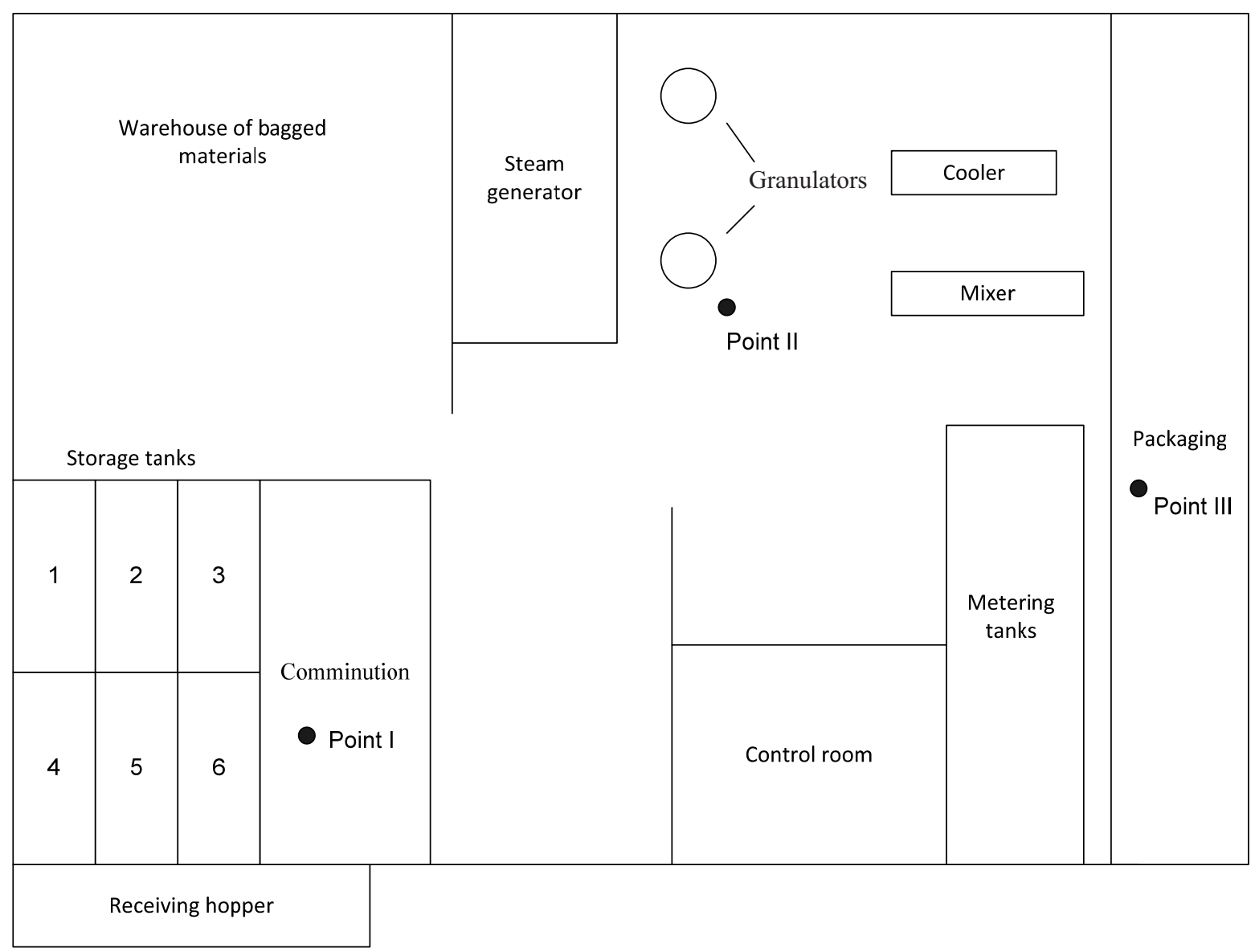

Fig. 1. Schematic diagram of feed plant floor plan. 
Table 1. Dust concentrations at specific points within the plant.

\begin{tabular}{|c|c|c|c|c|c|}
\hline Location & $\begin{array}{l}\text { Size } \\
{[\mathrm{mm}]}\end{array}$ & $\begin{array}{l}\text { Dust concentration max. } \\
{\left[\mathrm{mg} / \mathrm{m}^{3}\right]}\end{array}$ & $\begin{array}{l}\text { Dust concentration min. } \\
{\left[\mathrm{mg} / \mathrm{m}^{3}\right]}\end{array}$ & $\begin{array}{l}\text { Dust concentration avg. } \\
{\left[\mathrm{mg} / \mathrm{m}^{3}\right]}\end{array}$ & $\begin{array}{l}\text { Dust - average daily } \\
\text { concentration }\end{array}$ \\
\hline \multirow{4}{*}{ Point I } & 1 & 0.504 & 0.138 & 0.2510 & 0.0623 \\
\hline & 2.5 & 0.678 & 0.428 & 0.4982 & 0.0461 \\
\hline & 4 & 0.947 & 0.663 & 0.7884 & 0.0526 \\
\hline & 10 & 1.760 & 0.677 & 1.2496 & 0.1669 \\
\hline \multirow{4}{*}{ Point II } & 1 & 0.305 & 0.116 & 0.1584 & 0.0266 \\
\hline & 2.5 & 1.150 & 0.327 & 0.5692 & 0.1879 \\
\hline & 4 & 1.190 & 0.373 & 0.6633 & 0.1578 \\
\hline & 10 & 2.110 & 0.740 & 1.0406 & 0.2676 \\
\hline \multirow{4}{*}{ Point III } & 1 & 0.191 & 0.098 & 0.1109 & 0.0148 \\
\hline & 2.5 & 0.292 & 0.228 & 0.2545 & 0.0131 \\
\hline & 4 & 0.394 & 0.285 & 0.3228 & 0.0196 \\
\hline & 10 & 0.779 & 0.339 & 0.4342 & 0.0521 \\
\hline
\end{tabular}

Petri dishes with the PDA medium were incubated at the temperature of $24^{\circ} \mathrm{C}$ for 72 hours, and the ones with the MA medium in $30^{\circ} \mathrm{C}$ also for 72 hours. Then all colonies of fungi grown on different levels were counted. Using selected taxonomic references qualitative composition was analysed taking into account macro- and microscopic characteristics of the fungi [15-18].

\section{Results}

Analysing the results of the concentration of the organic dust in the air, it can be concluded that at any point the average concentration did not exceed the value of the PEL, i.e. 2 $\mathrm{mg} / \mathrm{m}^{3}$. The highest short-term exposure concentration of dust occurred at point II, i.e. granulation stage $\left(2.11 \mathrm{mg} / \mathrm{m}^{3}\right)$, and its level is not within the acceptable limits (Table 1).

The results confirm the trend observed in the study carried out by Buczaj [19], who assessed the concentration of dust on select workstations at industrial mills in Lublin Province. The average dust concentration at a packer workstation was around $0.10 \mathrm{mg} / \mathrm{m}^{3}$, which is similar to that at the presently analysed plant. By contrast, though, in the cited study the highest average total dust concentration occurred at a workstation of an elevator operator. It was much higher than at the granulation stage of the process in the analysed plant and several times exceed the PEL (22.98 $\mathrm{mg} / \mathrm{m}^{3}$ ). Also, the research performed in Canadian mills by Karpaciński [20] confirms high levels of dust pollution in grain processing plants, in which the researcher showed the concentration of dust in quantities exceeding $10 \mathrm{mg} / \mathrm{m}^{3}$. The obtained results allow us to conclude that the dust level in the examined feed mill is much lower than in cerealmilling plants, in which there are significant exceedances of hygienic standards.
Table 2 shows a summary of all the colonies of mould fungi grown on different stages of the impactor. Altogether, 8,035 colonies of mould fungi grew from the samples taken. The largest number of mould fungi in the air was present at point $\mathrm{I}$, where comminution of raw materials takes place. At this position as many as 4,871 mould fungi colonies grown on PDA and MA media were counted. At the packaging stage of production the number of mould fungi present decreased threefold.

Unlike in the case of most physical and chemical agents there are no relevant provisions relating to the microbiological control of indoor air in Polish legislation. Also, worldwide there are no commonly accepted evaluation criteria and broadly recognized norms and methodological recommendations. Considering the absence of generally agreed guidelines for the microbiological quality of air, its assessment is made on the basis of hygienic standards defining the threshold concentration of microorganisms in the air in relation to particular classes of premises. Determination of the normative values is carried out with reference to the studied environments and types of environmental samples [21, 22].

According to the literature of the subject the degree of microbial contamination of air should not exceed the level of $6 \cdot 10^{2} \mathrm{cfu} / \mathrm{m}^{3}$ (cfu: colony forming units) [22]. By adopting such a criterion, the microbiological condition of the air in the studied feed mill can be considered satisfactory.

Table 3 presents the percentage share of respective species of mould fungi determined in the studied samples on the basis of their macro- and microscopic characteristics. By comparison, Table 4 summarizes the total percentage share of moulds isolated from all tested samples. The predominant type of mould present in feed mill air turned out to be Aspergillus candidus, which accounted for $54.15 \%$ of all species of mould fungi isolated from samples taken. 
Table 2. Number of mould colonies grown.

\begin{tabular}{|c|c|c|c|c|c|c|}
\hline \multirow{2}{*}{$\begin{array}{l}\text { Stage at which Petri } \\
\text { dish was placed in } \\
\text { Andersen impactor }\end{array}$} & \multicolumn{2}{|c|}{ Point I } & \multicolumn{2}{|c|}{ Point II } & \multicolumn{2}{|c|}{ Point III } \\
\hline & PDA & MA & PDA & MA & PDA & MA \\
\hline 1 & 434 & 894 & 224 & 436 & 260 & 426 \\
\hline 2 & 370 & 790 & 172 & 384 & 100 & 368 \\
\hline 3 & 342 & 709 & 40 & 220 & 19 & 156 \\
\hline 4 & 68 & 663 & 19 & 73 & 9 & 69 \\
\hline 5 & 51 & 435 & 13 & 48 & 4 & 56 \\
\hline 6 & 20 & 95 & 2 & 16 & 3 & 47 \\
\hline In total & \multicolumn{2}{|c|}{4,871} & \multicolumn{2}{|c|}{1,647} & \multicolumn{2}{|c|}{1,517} \\
\hline
\end{tabular}

Table 3. The percentage share of the various species of mould fungi in the collected samples.

\begin{tabular}{|c|c|c|c|c|c|c|}
\hline \multirow{2}{*}{ Mould fungi species } & \multicolumn{2}{|c|}{ Point I } & \multicolumn{2}{|c|}{ Point II } & \multicolumn{2}{|c|}{ Point III } \\
\hline & Quantity & $\%$ & Quantity & $\%$ & Quantity & $\%$ \\
\hline Absidia corymbifera & 26 & 0.53 & 3 & 0.18 & 9 & 0.59 \\
\hline Aspergillus candidus & 2460 & 50.50 & 936 & 56.83 & 955 & 62.95 \\
\hline Aspergillus flavus & 1853 & 38.04 & 249 & 15.12 & 340 & 22.41 \\
\hline Aspergillus fumigatus & 464 & 9.53 & 425 & 25.80 & 161 & 10.61 \\
\hline Eurotium amstelodami & 4 & 0.08 & 1 & 0.06 & - & - \\
\hline Mucor racemosus & 3 & 0.06 & 2 & 0.12 & 9 & 0.59 \\
\hline Penicillium polonicum & 1 & 0.02 & 3 & 0.18 & 4 & 0.26 \\
\hline Penicillium glabrum & 54 & 1.11 & - & - & - & - \\
\hline Rhizopus oryzae & 5 & 0.10 & 3 & 0.18 & 2 & 0.13 \\
\hline Trichophyton sp. & 1 & 0.02 & 1 & 0.06 & 1 & 0.07 \\
\hline Acremonium spp. & - & - & 2 & 0.12 & 11 & 0.73 \\
\hline Aspergillus clavatus & - & - & 1 & 0.06 & - & - \\
\hline Aspergillus restrictus & - & - & 3 & 0.18 & 7 & 0.46 \\
\hline Aspergillus terreus & - & - & 2 & 0.12 & - & - \\
\hline Aureobasidium pullulans & - & - & 1 & 0.06 & - & - \\
\hline Curvularia lunata & - & - & 1 & 0.06 & - & - \\
\hline Penicillium spp. & - & - & 5 & 0.30 & - & - \\
\hline Trichoderma spp. & - & - & 9 & 0.55 & 1 & 0.07 \\
\hline Alternaria alternata & - & - & - & - & 1 & 0.07 \\
\hline Aspergillus oryzae & - & - & - & - & 2 & 0.13 \\
\hline Cladosporium spp. & - & - & - & - & 1 & 0.07 \\
\hline Emericella spp. & - & - & - & - & 1 & 0.07 \\
\hline Penicillium waksmanii & - & - & - & - & 12 & 0.79 \\
\hline In total & 4,871 & 100 & 1,647 & 100 & 1,517 & 100 \\
\hline
\end{tabular}


Table 4. The total percentage share of mould fungi isolated from all samples taken at the feed plant.

\begin{tabular}{|l|c|c|}
\hline \multicolumn{1}{|c|}{ Mould fungi species } & Quantity & $\%$ \\
\hline Absidia corymbifera & 38 & 0.47 \\
\hline Acremonium spp. & 13 & 0.16 \\
\hline Alternaria alternata & 1 & 0.01 \\
\hline Aspergillus candidus & 4,351 & 54.15 \\
\hline Aspergillus clavatus & 1 & 0.01 \\
\hline Aspergillus flavus & 2,442 & 30.39 \\
\hline Aspergillus fumigatus & 1,050 & 13.07 \\
\hline Aspergillus oryzae & 2 & 0.02 \\
\hline Aspergillus restrictus & 10 & 0.12 \\
\hline Aspergillus terreus & 2 & 0.02 \\
\hline Aureobasidium pullulans & 1 & 0.01 \\
\hline Cladosporium spp. & 1 & 0.01 \\
\hline Curvularia lunata & 1 & 0.01 \\
\hline Emericella spp. & 1 & 0.01 \\
\hline Eurotium amstelodami & 5 & 0.06 \\
\hline Mucor racemosus & 14 & 0.17 \\
\hline Penicillium polonicum & 8 & 0.10 \\
\hline Penicillium glabrum & 54 & 0.67 \\
\hline Penicillium spp. & 5 & 0.06 \\
\hline Penicillium waksmanii & 12 & 0.15 \\
\hline Rhizopus oryzae & 10 & 0.12 \\
\hline Trichoderma spp. & 10 & 0.12 \\
\hline Trichophyton sp. & 35 & 0.04 \\
\hline In total & 100.00 \\
\hline
\end{tabular}

In the samples from point III its share was almost $63 \%$. Aspergillus flavus was the second most numerous type of mould present in the feed plant. Its total share within the tested samples was $30.39 \%$, while among the ones from point I (comminution) it accounted for up to $38 \%$. Another large group was composed of moulds of family Aspergillus fumigatus, whose total number of colonies reached 1,050 (13\%). In the samples from point II (granulation), they accounted for $25 \%$ of all isolated species. Other species of mould fungi were present in small amounts, not exceeding $1 \%$ of all the species isolated from individual samples.

Kreqgiel [23] investigated the microbial contamination of air within a process room of a facility producing individual packages for the food industry. She noted that the contamination of mould origin ranged from about 600 to 1,300 $\mathrm{cfu} / \mathrm{m}^{3}$, and its level depended on the season. These values were significantly lower than in the case of the studied feed mill, which is a result of industry-specific characteristics. Moulds of the following genera occurred mainly in the air of the process room: Penicillium, Alternaria, and Cladosporium spp., which is in contrast to the samples taken from the feed plant, where they did occur in trace amounts.

In feed plants the main sources of mould are raw feed materials of plant origin and their treatment. The identified contamination among the cereals, which are often feed ingredients, is not greater than $10^{4} \mathrm{cfu} / \mathrm{g}[24,25]$. The amount of mould in the material for feed depends on its moisture content, and feed mixing environment, including the temperature and the availability of oxygen. The presence of moulds entails the risk of mycotoxicoses diseases induced by mycotoxins (secondary metabolites of moulds, especially of the genera: Penicillium, Aspergillus, and Fusarium). Mycotoxins are extremely dangerous due to their carcinogenic, mutagenic, teratogenic, and neurotoxic actions. Among animals, mycotoxins cause a decrease in feed efficiency, deterioration of health, and immunosuppression. Animal mycotoxicoses through contaminated food of animal origin may cause mycotoxicoses in humans $[26,27]$. Mould toxins may cause disorders of an acute or chronic nature. Aflatoxins from Aspergillus flavus are known carcinogens. Aflatoxins lead to liver damage, including its fibrosis, and aflatoxin B1 may cause hepatocellular carcinoma. Furthermore, aflatoxin B1 was detected in lung tissue of people who died of respiratory cancer, and who worked in an environment highly contaminated with moulds. Another of the mycotoxins, ochratoxin A, induces the formation of tumors of the upper sections of the urinary tract and is often the cause of kidney disorders - especially mycotoxic nephropathy [28].

In addition, occupational exposure to organic dust may lead to many respiratory illness syndromes such as diseases of allergic nature: extrinsic allergic alveolitis (EAA), alveolitis allergica, bronchial asthma, allergic rhinitis, allergic conjunctivitis, allergic diseases, and immunotoxic-based diseases (organic dust toxic syndrome or ODTS, "sick building syndrome") [7].

The moulds of genera Penicillium and Aspergillus are among the fungi posing the greatest threat to workers of a feed-mixing plant. They may cause occupational asthma. The results of the study show that moulds of the genus Aspergillus, especially the ones of species Aspergillus fumigatus, prevailed in the examined feed production plant. Fungi of the genus Aspergillus can cause immunotoxicbased respiratory disease, also known as aspergillosis. They may also cause allergies [29].

Allergic bronchopulmonary aspergillosis is caused by inhalation of spores of fungi of genus Aspergillus. These spores are not eliminated from the respiratory tract and form colonies growing in the lumen of the bronchi. Acute inflammatory response caused by fungal protease and cytokines released from the eosinophils cause destruction of lung epithelial cells [30]. This leads to chronic bronchitis and destruction of lungs and pulmonary fibrosis [31].

Some of the mould allergens have been well characterized. They are mainly proteins. Allergens isolated from 
spores and mycelium of Aspergillus fumigatus have a molecular weight of 11 to $90 \mathrm{kDa}$ [32]. Allergens Asp f2 $(37 \mathrm{kDa})$ and Asp f4 (30kDa) are responsible for developing bronchopulmonary aspergillosis. On the other hand, hypersensitivity to proteins Asp f3 (18 kDa) and Asp f5 (42 kDa) causes allergic asthma [33]. Also, enzymes produced by moulds are responsible for allergic reactions. Phosphatase (produced by $A$. niger) or beta-glucosidase (produced by fungi of the genus Aspergillus), which is added to animal feed in order to improve its digestibility and enhance the nutritional value [34], should be mentioned in this regard.

\section{Conclusions}

The performed study enabled the assessment of working conditions at various workstations in a feed mill.

Research on present concentrations of airborne organic dust has led to the conclusion that the PEL values were not exceeded, and the highest short-term exposure concentration of dust was recorded at the granulation stage.

The dominant airborne microflora in the feed mill was composed of mould fungi of genus Aspergillus: candidus, flavius, and fumigatus. They accounted for about $97 \%$ of isolated species from all tested samples. The most contaminated samples came from point I (comminution).

Bearing in mind the threat posed by the presence of dust and mould on workstations in feed mills, the level of dust and mould contamination of the air in production plants must be continuously controlled.

\section{References}

1. CHEW A. L., MAIBACH H. I. Occupational issues of irritant contact dermatitis. Int. Arch. Occup. Environ. Health. 76, 339, 2007.

2. THONG H., MAIBACH H. I. Irritant dermatitis as a model of inflammation. Drug Discov. Today Dis. Mech. 5, (2), 221, 2008.

3. SLODOWNIK D., LEE A., NIXON R. Irritant cotact dermatitis: A review. Australas J Dermatol. 49, 1, 2008

4. NICHOLSON P., LLEWELLYN D., ENGLISH J. Evidence-based guidelines for the prevention, identification and management of occupational contact dermatitis and urticarial. Contact Dermatitis. 63, 177, 2010.

5. ANTTILA S., BOFFETTA P. Occupational Cancers. Springer: London, pp. 583-590, 2014.

6. NARBUTT J., LESIAK A., ERKIERT A., SYSAJĘDRZEJOWSKA A. Non-melanoma skin cancer development and environmental Factors. Pol. J. Environ. Stud. 14, (5), 545, 2005.

7. POOLE J. A., ROMBERGER D., J. Immunological and Inflammatory Responses to Organic Dust in Agriculture. Curr Opin Allergy Clin Immunol. 12, (2), 126, 2012.

8. PARIS C., NGATCHOU-WANDJI J., LUC A., MCNAMEE R., BENSEFA-COLAS L., LARABI L., TELLE-LAMBERTON M., HERIN F., BERGERET V., BROCHARD P., CHOUDAT D., DUPAS D., GARNIER R., PAIRON J., AGIUS R. M., AMEILLE J. Work-related asthma in France: recent trends for the period 2001-2009. Occup Environ Med. 69, (6), 391, 2012.
9. KIEĆ-ŚWIERCZYŃSKA M. Allergic contact dermatitis. Pathomechanism. Alergia. 1, 33, 2009 [In Polish].

10. JEEBHAY M. F. Work-related asthma. CME. 27, (11), 496, 2009.

11. ZALEWSKA M., WAŁAMANIUK M., PAWIŃSKA M., SZPAK A., HUZARSKA D., KOMOROWSKA E. Workplace Heath threats and their effects in Podlasie Region. Pol. J. Environ. Stud. 17, (5), 797, 2008.

12. PAŁCZYŃSKI C., KIEĆ-ŚWIERCZYŃSKA M. Allergology and Clinical Toxicology in the rural environment. IMP: Łódź, 2000 [In Polish].

13. KIEĆ-ŚWIERCZYŃSKA M., KRECISZ B. Professional allergology. IMP: Łódź, pp. 151-161, 2008 [In Polish].

14. BUDNIK L., BAUR X. The Assessment of environmental and occupational exposure to hazardous substances by biomonitoring. Dtsch Arztebl Int. 106, (6), 91, 2009.

15. KRZYŚCIAK P., SKÓRA M., MACURA A.B. Atlas of human pathogenic fungi. $1^{\text {st }}$ ed. MedPharm Polska: Wrocław, 2011 [In Polish].

16. LARONE D.H. Medically Important Fungi- a guide to identification. $5^{\text {th }}$ ed. ASM Press: Washington, 2011.

17. HOUBRAKEN J., FRISVARD J., SAMSON R. Taxonomy of Penicillium citrinum and related species. Fungal Diversity. 44, 117, 2010

18. PITT J.I., HOCKING A. D. Fungi and food Spoilage. $3^{\text {th }}$ ed. Springer: New York, 2009.

19. BUCZAJ A. Dustiness level in selected grain processing industry plants in Lubelskie voivodeship. IR. 1, (126), 7, 2011 [In Polish].

20. KARPACIŃSKI E.A. Exposure to inhalable flour dust in Canadian flour mills. Appl Occup Environ Hyg. 18, (12), 1022, 2003.

21. LELIEVED H., HOLAH J., NAPPER D. Hygiene in food processing. Principles and practice. $2^{\text {th }}$ ed. WP: Cambridge, 2013.

22. GÓRNY R. Biohazards: standards, guidelines, and proposals for threshold limit values. PiMOŚP, 3, (41), 17, 2004 [In Polish].

23. KRĘGIEL D. The Microbial Contamination of a Technological Shop-Floor Air and The Quaity of Packagins Manufactured. ŻNTJ. 1, (46) Suppl, 52, 2006 [In Polish].

24. ŻUKIEWICZ-SOBCZAK W., CHOLEWA G., KRASOWSKA E., ZWOLIŃSKI J., SOBCZAK P., ZAWIŚLAK K., CHMIELEWSKA-BADORA J., PIĄTEK J., WOJTYŁAA. Pathogenic fungi in the work environment of organic and conventional farmers. Post Dermatol Alergol. 29, (4), 256, 2012.

25. ŻUKIEWICZ-SOBCZAK W., CHOLEWA G., KRASOWSKA E., CHMIELEWSKA-BADORA J., ZWOLIŃSKI J., SOBCZAK P. Rye grains and the soil derived from under the organic and conventional rye crops as a potential source of biological agents causing respiratory diseases in farmers. Post Dermatol Alergol. 30, (6), 373, 2013.

26. GRAJEWSKI J., BŁAJET-KOSICKA A., TWARUŻEK M., KOSICKI R. Occurrence of mycotoxins in Polish animal feed in years 2006-2009. J. Anim Physiol Anim Nutr. 96, (5), 870, 2012.

27. SAPKOTA A. R., LEFFERTS L. Y., MCKENZIE S., WALKER P. What do we feed to food-production animals? A review of animal feed ingredidients and their potential impacts on human healt. EHP. 115, (5), 663, 2007.

28. WHO. Environmental health criteria. Mycotoxins. PZWL: Warszawa, Vol 11, 1984 [In Polish]. 
29. GERARDI M.H., ZIMMERMAN M.C. Wastewater pathogens. John Wiley \& Sons: New Jersey, 2005.

30. CRAMERI R., ZELLER S., GLASER A. G., VILHELMSSON M., RHYNER C. Cross-reactivity among fungal allergens: a clinically relevant phenomenon? Mycoses. 52, (2), 99, 2009.

31. PATTERSON K., STREK M. E. Allergic Bronchopulmonary Aspergillosis. AJRCCM. 7, (3), 237, 2010.

32. PANT H., SCHEMBRI M., WORMALD P., MACARDLE P.
IgE-mediated fungalallergy in allergic fungal sinusits. Laryngoscope. 119, (6), 1046, 2009.

33. KNUSTEN A. P., BUSH R. K., DEMAIN J. G., DENNING D. W., DIXIT A., FAIRS A., GREENBERGER P. A., KARIUKI B., KITA H., KURUP V. P., MOSS R. B., NIVEN R. M., PASHLEY C. H., SLAVIN R. G., VIJAY H. M., WARDLAW A. J. Fungi and aergic lower respiratory tract diseases. J Allergy Clin. Immunol. 129, (2), 280, 2012.

34. TARLO S. M., LISS G. M. Prevention of occupational asthma. Curr Allergy Ashma Rep. 10, 278, 2010. 
